\title{
Karel Čapek's Graphic Britain: \\ A study of the visual intermodernism of Čapek's Letters from England
}

\author{
Jeremy Howard (jch2@st-andrews.ac.uk) \\ School of Art History, University of St Andrews, St Anrews, United Kingdom
}

\begin{abstract}
Best known as a science-fiction writer, Karel Čapek's drawings from his 1924 tour of Great Britain are here analysed in terms of what is categorised as 'intermodernism.' As an integral part of the travelogue he published in English as Letters from England, they are seen as coordinates for navigating identity, detailing, through their construction and composition of lines, a subtle and perceptive understanding of difference and unity. That they are biographical as well as ostensibly documentary is conveyed through exploring the development of their visual language and its blending of modernist and historic conventions. Simultaneously, their assessment of society and nature is revealed as a nuanced explication of community and place. Čapek's visual journey beyond the country of his birth is evaluated in terms of the meanings to be found in the acute, quirky and ironic nature of his drawings. Ultimately, the distinctions in form, seeing and understanding are revealed in terms of Čapek's non-canonical, synthetic and humanist intermodernism.
\end{abstract}

\section{Keywords}

Karel Čapek; Travel literature; intermodernism; England; Scotland; London; Liverpool; Glasgow 


\title{
Karel Čapek's Graphic Britain: A study of the visual intermodernism of Čapek's Letters from England
}

\author{
Jeremy Howard
}

\section{Introduction}

Published in English, first through serialisation in the Manchester Guardian between 20 September and 8 November 1924 and then in book form in March 1925, Karel Čapek's collected Letters from England comprise the first of four self-illustrated travelogues that appeared in the 1920s and 1930s. ${ }^{1}$ With his inimitable whimsical, impressionistic and individual style, Čapek's visual and literary tour of Britain set out the stall for what he would subsequently do with his visits to Spain, the Netherlands and Scandinavia. ${ }^{2}$ As such, it introduced his quirky, humorous yet serious study of culture and customs that we might best describe as 'intermodernist.' The term comes from the work of Kristin Bleumel, who has described it and the device of intermodernism thus:

... intermodernism deconstructs multiple binaries, not just the highbrow / lowbrow opposition. So while intermodernism might initially function as modernism's other in academic practice, it has the potential to be the concept or space that inserts itself between modernism and its many structuring oppositions, reshaping the ways we think about relations between elite and common, experimental and popular, urban and rural, masculine and feminine, abstract and realistic, colonial and colonised.3

Bleumel has gone on to define her term as a retroactive invention of an interdisciplinary category applicable to a certain modern 'kind' or 'movement' of creative work produced between 1920 and 1950 that is at once aesthetic, institutional (materialist) and ideological. As such it is both a 'critical compass' and an 'analytical tool' designed as a revisionary, eccentric and radical interjection in the field of cultural studies. ${ }^{4}$

1) The book appeared as Karel Čapek, Letters from England, translated by Paul Selver, London: Geoffrey Bles, 1925. It was presaged by the first Czech edition of his Letters from Italy, i.e. Italské listy, Prague: Aventinum, 1923. However, this appeared without images, and when an English translation was eventually published it only included six highly conventional drawings of well-known sites by Richard Howard Penton, Letters from Italy, London: Besant \& Co., 1929. The self-illustrated travelogues were posthumously followed by his Letters from Home (see below).

2) The first editions of the other three 'foreign' travelogues were published as follows: Letters from Spain, translated by Paul Selver, London: Geoffrey Blas, 1931, after the Czech edition Výlet do Španěl, Prague: Aventinum, 1930; Letters from Holland, translated by Paul Selver, London: Faber and Faber, 1933, after Obrázky z Holandska, Prague: Aventinum, 1932; and Travels in the North, translated by M. and R. Weatherall, London: George Allen \& Unwin, 1939, after Cesta na sever, Prague: Fr. Borový, 1936.

3) Kristin Bleumel, 'Introduction', in Kristin Bleumel ed., Intermodernism: Literary Culture in Mid-Twentieth-Century Britain, Edinburgh: Edinburgh University Press, 2009, 4.

4) Ibid. 4-5. 
Playing with the attributes of avant-garde formalism and conventional visual illusionism, Čapek navigated a non-canonical artistic middle path through British society. An essential ingredient of this was his eccentric, interwoven exploration of history and modernity, town and country, tradition and innovation. Hence Čapek articulated vital interlocking facets of art, architecture and design, both contemporary and historic, revealing through his graphic language how they coalesce into what he conceives as relational material culture. In so doing he extrapolated, exaggerated and distorted in order to convey truths and aspects with a freedom and insight of an outsider from a foreign culture little known to those he observed. His lack of personal investment in British society and his being informed by a continental, indeed Czech, humanitarian background resulted in a rare form of behavourist encapsulation of British social relations. This involved visual analysis of both the seemingly irrational and natural performance of those relations as witnessed in material culture. As such, through the drawings of Letters from England, Čapek creatively enquired into social process and agency, his interpretation being conditioned by an attempt to both locate and contextualise the modes he observes. Ultimately, this attempt dovetailed with his vocation, as close confidant and political ally of President Tomáš Masaryk, to simultaneously configure and articulate, for both international and local community consumption, a sense of correlated place and identity for newly founded, empire-ridden, Czechoslovakia. ${ }^{5}$

Karel Čapek (1890-1938) was a pioneer. His intellectual and artistic prowess was amply illustrated through his interwar literary output when he emerged as one of Czechoslovakia's most insightful and incisive commentators on, for instance, socio-political trends, human folly and questions of aesthetics. Often exploiting modernist idioms of constructive deconstruction, his ability to both invent with high craft yet simultaneously speak with a language marked by a common touch made him stand out among his contemporaries. He joined the most radical new Czech artists association Skupina (The Group), along with his painter-writer brother Josef, when it was formed in 1911 and, like his brother, was able to build upon its advocacy of Cubist principles. But, also like his brother, Čapek was not to be constrained by the Skupina leadership's calls for Cubist orthodoxy and left a year later to go his own experimental way. In the wake of the First World War, that path included both Čapek brothers heading the Tvrdošijni (Stubborn Ones) group, whose stylistic diversity has been critically intimated by conflated categories, such as 'conscious primitivism,' 'expressionist naturalism' and 'crystal cubism.' In Letters from England Čapek followed suit, with his version of crystalline modernism, derived as it is from his experience of 'Gothic' crystals in London's Natural History Museum, being axial. Since our principal concern is Čapek's visualised study of a cultural patchwork, we read his British drawings as a major counterpart to his literary probing of a distinct-yet-common identity. With this in mind this article examines his sketches in terms of their combination of elements of figuration and abstraction, this conveying awareness of diverse modernist trends, opposition to ideological

5) Čapek's recounting of Masaryk's autobiography (initially K. Č. Hovory s T. G. Masarykem, Prague: Čin, 1929-1935) was published in multiple editions and translated into at least nine languages. It was first published in English as Karel Čapek, President Masaryk tells his Story, London: George Allen \& Unwin, 1934.

6) Concerning Skupina and Tvrdošijni as well as the wider Czech modernist context, see, for example, Marie Rakušanová, 'Prague-Brno: Expressionism in Context,' in Isabel Wünsche, ed., The Routledge Companion to Expressionism in a transnational context, New York: Routledge, 2018, 33-55. 
and aesthetic absolutism, and also an abiding, pedagogic, concern for a readily learnable lexicon of life.

This then is Čapek's intermodernism. While comprising his most signficant self-illustrated work, Letters from England, along with his subsequent travelogues, can be viewed alongside two others in his oeuvre for which he creates narrative images. One of these, Dashenka, Or the Life of a Puppy (1933), is a children's story with a mix of doggy cartoons and photographs whose simple tales of canine learning simultaneously, and eloquently, convey Čapek's concern with human development. ${ }^{7}$ The other, Pictures from Home (1954), is a posthumously published collection of his columns focused on Bohemia (including a section on Prague) and Slovakia. ${ }^{8}$ As such, it is this second book that provides the closest parallel to the visual interpretations of cultural dynamics found in Letters from England. That said, it contains just thirty images, most of these relating to fishing, mountain holidaying and Slovak country life. Nevertheless, it also includes a sketch borrowed from the British travelogue, which accompanies a written reference to his earlier observation of British ways of being.

Čapek's representation of British environments, from the busy, assertive, restrictive and converging diagonals of metropolises to his more visually illusionistic and expansive treatment of country life, is particularly significant for our reading. This article analyses his approach to habitation and space, with its relish of things local, and of harmonised relations between man and nature (often denied in his British experience), in terms of his preferred combinations of curved and straight lines, which convey his deep desire for peaceful community based on continuity between present and past. In fact, his visual criticism of the British metropolis and relative appreciation of the British vernacular (especially as found in provincial Scotland) relates to the critique of technology, industrial progress and urban life that was prevalent in his anti-authoritarian, dystopian, fictional writing. It is the latter for which he is well known, both in his homeland and internationally, whether through the ultimately human-destroying, robot-controlled world of his play R.U.R. (1920), for example, or the satricial indictment of socially divisive and militaristic European and USA politics that was his 1936 science-fiction novel War with the Newts.

This advocacy of the local can be compared with Čapek's quest for signs of early human presence and explored alongside his visual valuing of the small within the larger whole. Its subtext is his contrasting antipathy to the contemporary hegemonic insensitivity to humane order that wreaks ugliness and disrespect. Through analysis of how he visualises his observations of Britain we encounter distinct modes of active form that starkly present his perception of a dichotomy between uplifting and corrupted being. Ultimately, then, this article suggests that Čapek's graphic British travelogue art, with its creative capture of a multiplicity of human design, merits attention as a key component of what I conceive as his intermodernism. If we approach it in the light of Bleumel's conception of intermodernism we thus see Čapek's visual language as possessing three bridging and salient features. It is: 1 ) cultural, and in this respect of 'the people' rather than the aristocracy or the establishment; 2) political, with an eccentric humane radicalism; and 3) artistic, possessing a commitment

7) Translated into English by M. and R. Weatherall, London: George Allen and Unwin, 1933.

8) Karel Čapek, Obrázky z domova, ed. Miroslav Halik, Prague: Československý spisovatel, 1954. To the best of my knowledge there remains no English translation. 
to being non-canonical, and mostly enunciated through the 'mass' genre of sketch, caricature and anecdote. For all their humour, parody, unreliability and selectivity, his images become navigational coordinates of social interaction replete with a distinctly personal dimension. As such they are by no means simple illustrations of literary text. This is confirmed by the fact that, for the most part, he created the images before writing the text.

The only scholarly work I am aware of that has undertaken a truly deep analysis of the visual aspect of Čapek's travelogues is Mirna Šolićs In Search of a Shared Expression: Karel Čapek's Travel Writing and Imaginative Geography of Europe. ${ }^{9}$ Her critically astute and well-informed reading of Čapek's approach to imagery and, with it, his creative 'intermedial narrative,' is highly enlightening. Her third chapter, 'Visual Travels,' explores the sense of the 'iconotext' that permeates the travelogues such that he creates a deliberately unreliable, subjective travel account in opposition to contemporary tourist guidebooks. That Čapek fictionalises the travel experience through his use of very selective and caricatural imagery is probed by Šolić so as to uncover his 'imaginative geographical' stance on folklore, the nature of Europe and, indeed, a higher supernatural realm. In the course of so doing, she analyses his aesthetic position with close regard to that of his brother Josef and other Czech modernists, as well as a range of other practitioners and theorists.

For all her erudite explication, Šolić's study is limited when it comes to evincing her argument from the images themselves. The title of her book gives away where her priorities lie, namely, in the literary aspects of Čapek's work. Furthermore, where she does explore Čapek's visual art, she does so mainly by means of a quick survey in order to confirm what she has discerned as a collective quality of, for instance, noise, the sedentary, movement or primitivism. Thus her study essentially reveals positions, context and formal traits that are not the focus of my enquiry. This being the case, there is more than ample scope for the interpretation offered here, which, as readers of both texts should comprehend, is distinctly complementary to that of Šolić. In this article, form and design are prioritised both for the extrication of meaning, as well as in their own right.

\section{Čapek’s graphic Britain: Perspectives crystallise}

Arriving on 28 May 1924, Čapek spent sixty days in Britain that summer. Feted by the recently founded International PEN [Poets, Essayists, Novelists] Club and with introductions provided by his young, then London-based, compatriot, linguist Otakar Vočadlo, he did most of his extensive travelling around Britain with Vočadlo. He was also well-supported by the Scotsman James Bone. He stayed at both men's family homes. The acquaintance with Bone is significant not only because the latter was London editor of the Manchester Guardian, where he placed more than half of Čapek's Letters from England, replete with drawings, but also due to the fact that he was the brother to the renowned graphic artist Muirhead Bone, whose lithographs of industrial Clydeside bear comparison, as we shall see, with Čapek's image of Glasgow. For reasons unclear at present, and despite the wealth of Čapek drawings reproduced in the Guard-

9) Mirna Šolić, In Search of a Shared Expression: Karel Čapek's Travel Writing and Imaginative Geography of Europe, Prague: Charles University, 2019. 
ian, none of the five urban views in Letters from England that I consider to be so revealing of his antipathy towards the British metropolis, with its face of ugly 'wilderness,' were included. ${ }^{10}$ Nevertheless, at the time, his skill in observing Britain artistically did gain notice in the local press:

Karel Čapek, the author of the R.U.R. and The Insect Play, who recently made an exhaustive tour of this country, has another outlet for his originality in pen and ink sketching. His pen was very busy when he was over here, making sketches of buildings and places, and anything out of the way that attracted him, besides caricatures of all sorts of personalities. He saw a lot of Great Britain in a comparatively short time, and returned to Prague with a full portfolio of sketches. ${ }^{11}$

Over its 192 or 149 pages (1924 and 2001 editions respectively), Letters from England contains seventy-seven (1924) or seventy-six (2001) Čapek drawings, of which a small selection, based on the principles outlined in the introduction, is analysed here.

\section{London lines}

Čapek, basically, did not like London. From the outset he railed against its inhumane streets and its traffic. He wrote that his depiction of congestion (29 / 38) (Figure 1) did not do justice to the torments wrought by its 'repugnant' travesty of modern civilisation: 'the real thing is even worse, because it roars like a factory' (31 / 37). The Traffic image, which is the first image conveying his experience of the British capital, adopts an elevated viewpoint high above the centre of a vast, seemingly never-ending, straight street in the middle of which are crammed lines of vehicles, all apparently stationary. In the wake of the pre-First World War celebration of the dynamic and technological modern city by artists such as Italian Futurists Umberto Boccioni and Gino Severini, Čapek's reductive modernism is distinctly anti-metropolitan. ${ }^{12}$ Thus

10) Two translations of Čapek's Anglické Listy, Prague: Aventinum, 1924, both entitled Letters from England, have been published as single volumes. The first is by Paul Selver (London: Geoffrey Bles, 1925), the second by Geoffrey Newsome (London: Continuum, 2001). They differ substantially, Newsome claiming (p. 15) to address the 'shortcomings... disappointing... standard... literal mistakes' of Selver. With regard this first citation, Newsome uses 'wilderness' as opposed to Selver's 'savagery' (from the Czech 'divočina'), pp. 69 and 73 respectively. Comparison between the translations and an early Czech edition (Prague: Borový, 1934) in terms of image placement reveals Newsome adhering relatively closely to the Czech, while Selver takes certain liberties. For a digitised version of the Czech, see: http://kramerius5.nkp.cz/view/uuid:de5e9970-ad99-11e3-b833-005056827e52?page=uuid:b59e9730-c54d11e3-94ef-5ef3fc9ae867 (accessed 20.04.2020). I have found that a combination of both translations can sometimes be useful hence my citations give page numbers for both sources, with Selver first. The Newsome translation edition pays scant regard to design and quality of reproduction. Indeed, in several instances the images are all but illegible. It squeezes a line of text onto the 'Traffic' image page despite having plenty of room for this on the page opposite. In his eleven page introduction he makes no mention of the images. However, in his 'Translator's Note' he acknowledges consciousness of them, if not their significance, by stating 'I... have repositioned his drawings so that they bear a more direct relation to the text' (p. 16).

11) 'Karel Capek,' Nottingham Evening Post, 23 September 1924. My own introduction to Čapek came fifty years later when, perhaps appropriately, I played the role of the Blind Ant in the Čapek brothers' Insect Play at school.

12) In this he may be compared with some of the British Vorticists, not least C.R.W. Nevinson, whose A Dawn, 1914 (c. 1915), was painted (and printed), in London, in opposition to the dehumanisations of war. Its stream-like ranks of soldiers with bayonetted rifles, represented from a centralised elevated viewpoint, are crammed between two rows of building with, as in the Čapek, a sense of congested confinement devoid of signs of relief. 


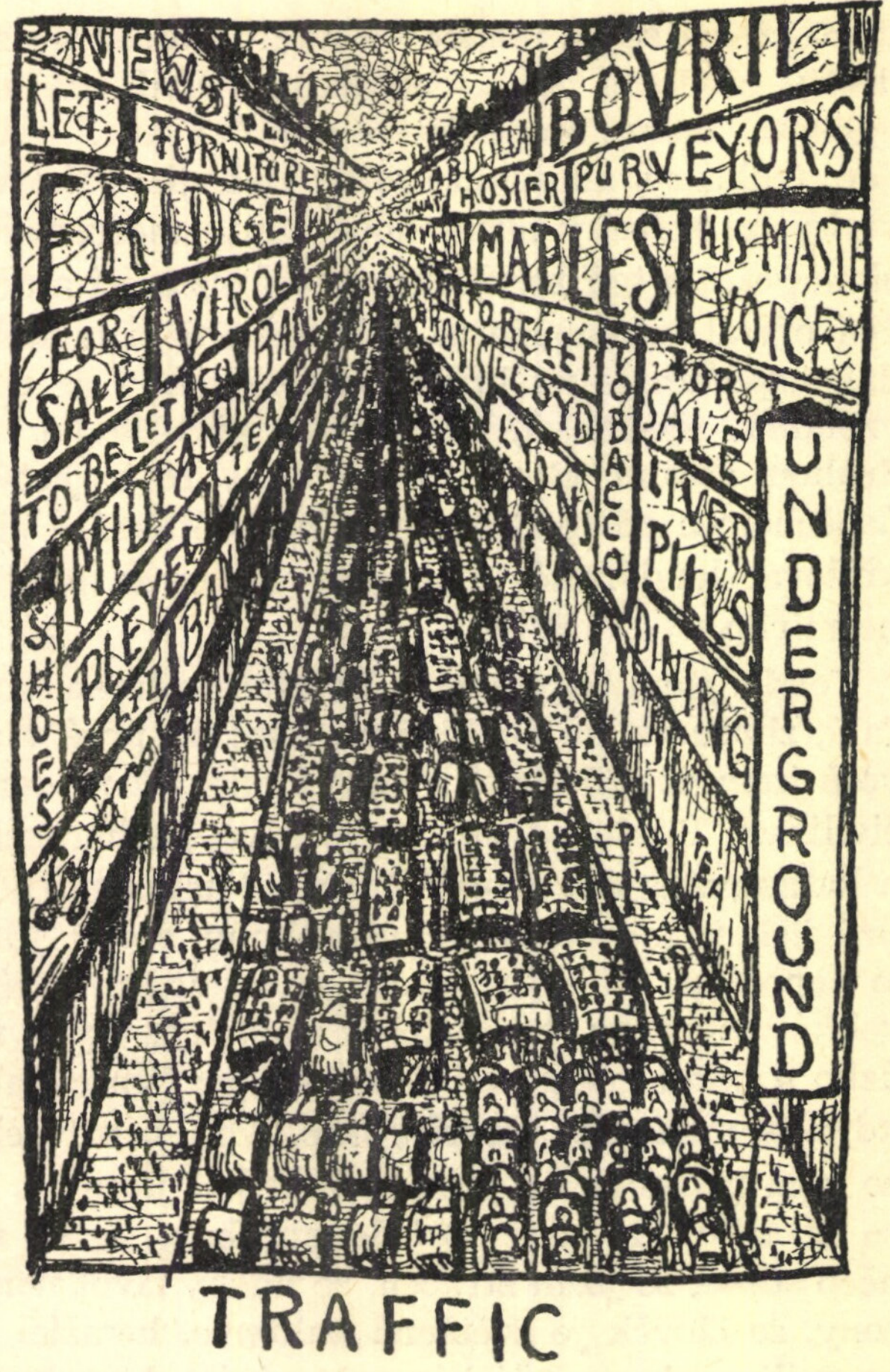

Figure 1: Karel Čapek, Traffic.

From Letters from England, London: Geoffrey Bles, 1925, 31. 
he turns a long straight street from London's commercial hub into an exercise in exaggerated single-point perspective where serried ranks of parallel lines converge at the infinitely distant vanishing point. The lines appear to be forcefully sucked in or belched out from that high, central point. As a result, we are presented with radiant lines of Gothic design given a secular dystopianism which contrasts with the light-shedding diagonals of Čapek's contemporary Lyonel Feininger, not least his 'Gothic cathedral' woodcut for the cover of the Bauhaus's programme (1919) (Figure 2).

Čapek's parallel lines are made all the more disturbing by their being filled with light squiggles, script and numerous tiny vertical dashes that represent humans. The squiggles are intensified, as if signifying smog, in the small inverted triangle of sky between the black serrations that represent chimneys. The opposing triangle to this is an elongated vertical wedge containing the squashed ranks of cars and buses. Divided by a central vertical axis, those on its left face away from the viewer, while those on its right appear frontally, in keeping with Britain's left side driving, yet all appear static and devoid of individuality.

Above the narrow angles of the ground-floors of the seemingly windowless tall buildings Čapek plays with rampant signboard culture. Emphasising what he discerned to be a distinct lack of aesthetic concern in street advertisement he shows repeated 'TO BE LET' and 'FOR SALE' signs squeezed in amongst other symbols of modern British, capitalist, living. This capitalist scream is a patchwork screen obliterating architecture, and at times it is generic, at times specific, i.e. Fridge, Furniture, Hosier, News, Shoes, Liver Pills, Dining, Tobacco, Underground; and Lyons [tea], Virol [health foods], Midland Bank, Lloyd [financial], Pleyel [pianos], Shoes, Bovril [beef extract paste], Abdulla [cigarettes], Maples [furniture], His Master's Voice [gramophone records], Bovis [builder]. ${ }^{13}$ With the exception of one 'Lyons' sign, whose cursive writing accords with that of contemporary Maison Lyons signage and package, all appear in upper-case letters, the vast majority of which are sans-serif. Thus, Čapek compiles a composite, negative, assemblage of Oxford Street, Tottenham Court Road and neighbouring West End thoroughfares. By placing 'UNDERGROUND' as an upwardpointing vertical rectangle and as the foremost of all the signage, it acts as a stop, reinforcing Čapek's contention that:

As such a congestion arises quite often, many people reflect... on what it will be like in twenty years... It has not yet been decided whether they are to walk on the roofs or under the earth; the only certain thing is that it cannot be done on the earth - which is a remarkable achievement of modern civilization (31 / 37).

Significantly, a review in The Times noted that these words contain 'only a shadow of the irony with which his largest drawing, Traffic, is invested. ${ }^{14}$ This critical appreciation of the image extended to his visual art per se, its nuanced observation being lauded over and above that of his written text:

13) Maples furniture store was at 141-150 Tottenham Court Road; His Master's Voice music record shop was at 363 Oxford Street.

14) Anon. 'England and the English. Some impressions of Karel Capek,' The Times, 13 March 1925, 10. 


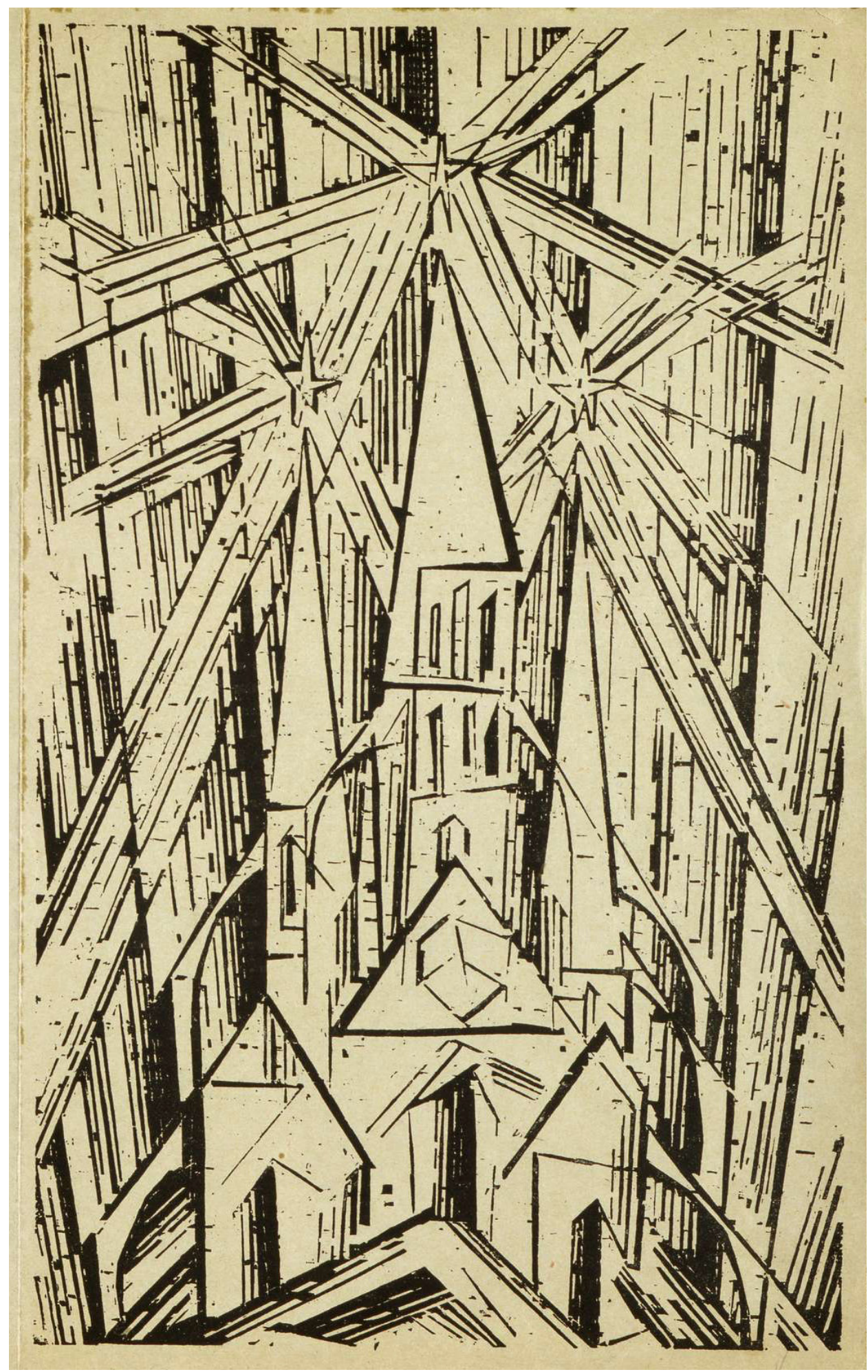

Figure 2: Lionel Feininger, Cathedral, Frontispiece to the Bauhaus Manifesto, Weimar, 1919. 
... if Mr. Capek's written word is sometimes of light import, the delightful illustrations with which his book is embellished are of the most serious and illuminating character. He is an artist of delicate wit and infinite suggestiveness... His drawings... convey with extraordinary economy a complete idea of his regard for us. ${ }^{15}$

To this may be added the conclusion of The Observer's review, which inadvertently discerned a trait of his most acerbic images with their elevated viewpoints: 'The book is always very rapid - it is, indeed, England seen from an aeroplane. It has the most delicious drawings by the author... ${ }^{16}$ Traffic sharply epitomises the dual fractal and collective nature of those drawings, thereby serving as a paradigmatic introduction for Čapek's intermodernist approach.

\section{Glasgow lines}

Glasgow fares little better than London under Čapek's pen and ink. For, again, he provides a visual interpretation from an elevated viewpoint looking down a straight street confined between blocks of buildings covered with bland, upper-case advertising (p. 129/110) (Figure 3). The nomenclature of these is still a chaotic mix of the general and the particular, though now there is a distinct sense of the downmarket locality. Thus, the particular is essentially a set of Scottish names, some of them fragmented, others indecipherable (e.g. McMarr, Mc Gi, McM..., Taylor, MacInnes, McP, McOwl, Smith), while the general is indicative of what Čapek described as the 'crude and grimy and sticky, noisy, reeking and oppressive, disorderly and cruel' Glasgow (129/110) that he quickly sought to escape, e.g. Hotel, Wholesale, Shipping, Dentures, Dresses, Agent, Bank, Hairdresser, Toilet Saloon, Diary, Bar, Sale, Coal, Agency, Pawnbroker, Tempera[nce?]... Light [?] Manufactory, Tobacco, Ltd.

In contrast to the projecting vertical 'UNDERGROUND' sign of London, here the foremost projecting signage is twofold. On the left, 'TOILET SALOON' is projected horizontally out over the street under a striped diagonal barber's pole with knob. Juxtaposed against this is the horizontal 'PAWNBROKER' sign from which are suspended the symbolic three Lombard spheres. That the barber's pole and pawnshop sign are both the most prominent and most decorated of the morass of signage in the image conveys Čapek's distress at Glasgow's 'life... forsaken by the breath of God' (128/110). That said, and despite there being no sign of an actual human being in the scene, the oppression is not so utter as London's. For while now the street is completely empty, there is also more room here for clear sky, and this, like the signs, is devoid of nervous squiggles. Furthermore, the buildings, for all their taint of insalubrity, imply a certain life beyond, through the inclusion of windows, doors, individualised chimney pots, cornices and a gable end. In addition, the viewpoint is not so high, and the street is curtailed by a dissecting view of the River Clyde replete with iron cranes, gantries, a ship, and tall industrial chimneys. As a result, the composition of Čapek's Glasgow contains less aggressive aerial perspective and less symmetry than his London and may be compared

15) Ibid.

16) Anon., 'As Mr. Capek sees us,' The Observer, 15 March 1925, 5. 


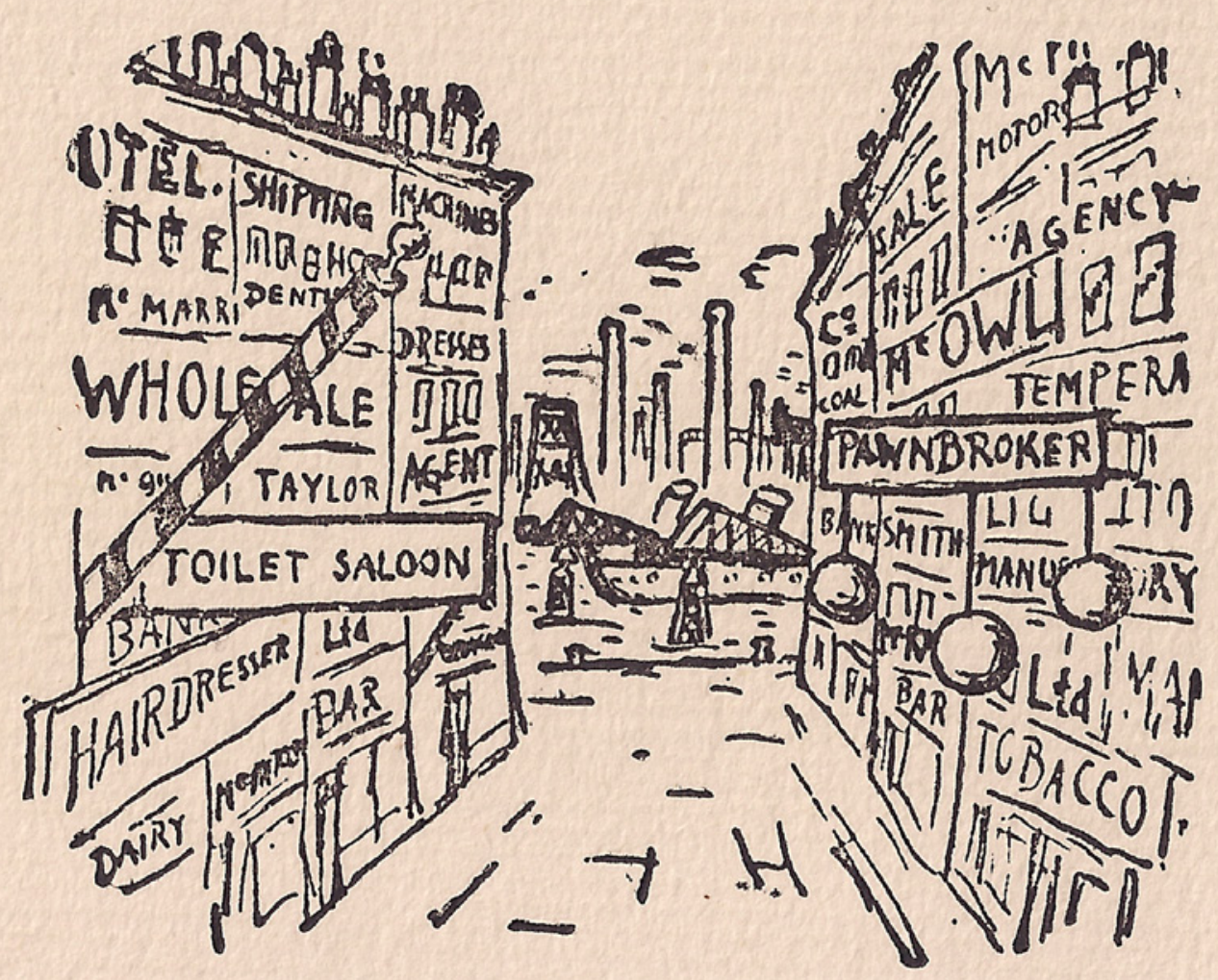

Figure 3. Karel Čapek, Glasgow.

From Letters from England, London: Geoffrey Bles, 1925, 129.

with Muirhead Bone's lithographs of the shipyards, despite lacking their championing of the wartime military industrial effort (e.g. Bone's widely disseminated, Ministry of Information commission, Shipyard seen from a crane, 1917) (Figure 4).

\section{From some Liverpudlian lines to a Bohemian "s crystal}

Čapek preferred Liverpool to London and Glasgow, his abandonment of the harsh angles of their ranked, converging parallel lines giving way to a broad view across the River Mersey with its variety of ships and boats bobbing on the water's gentle waves (162/128) (Figure 5). So, while the crammed, industrial port beyond is a 'vast, dirty and noisy' place (164/130), with its frenetic lines representing warehouses, smoking factory chimneys, cranes, masts, funnels and the harbour wall, this scene of 'quantity, confusion and expanse' (163/129) is distant and enveloped by plentiful sky and water. These provide solace as well as scope for the human spirit to 'sail forth' (164/130), to avoid the 'somewhat narrow... horizon' of his landlocked homeland, to find beauty in 'departure and arrival' (163/129) and to 'indulge in thought' (163/129).

The opportunity and ambiguity of Čapek's Liverpudlian vision is worth comparing with the image of creative potential he provides in the wake of his visit to London's Natural 


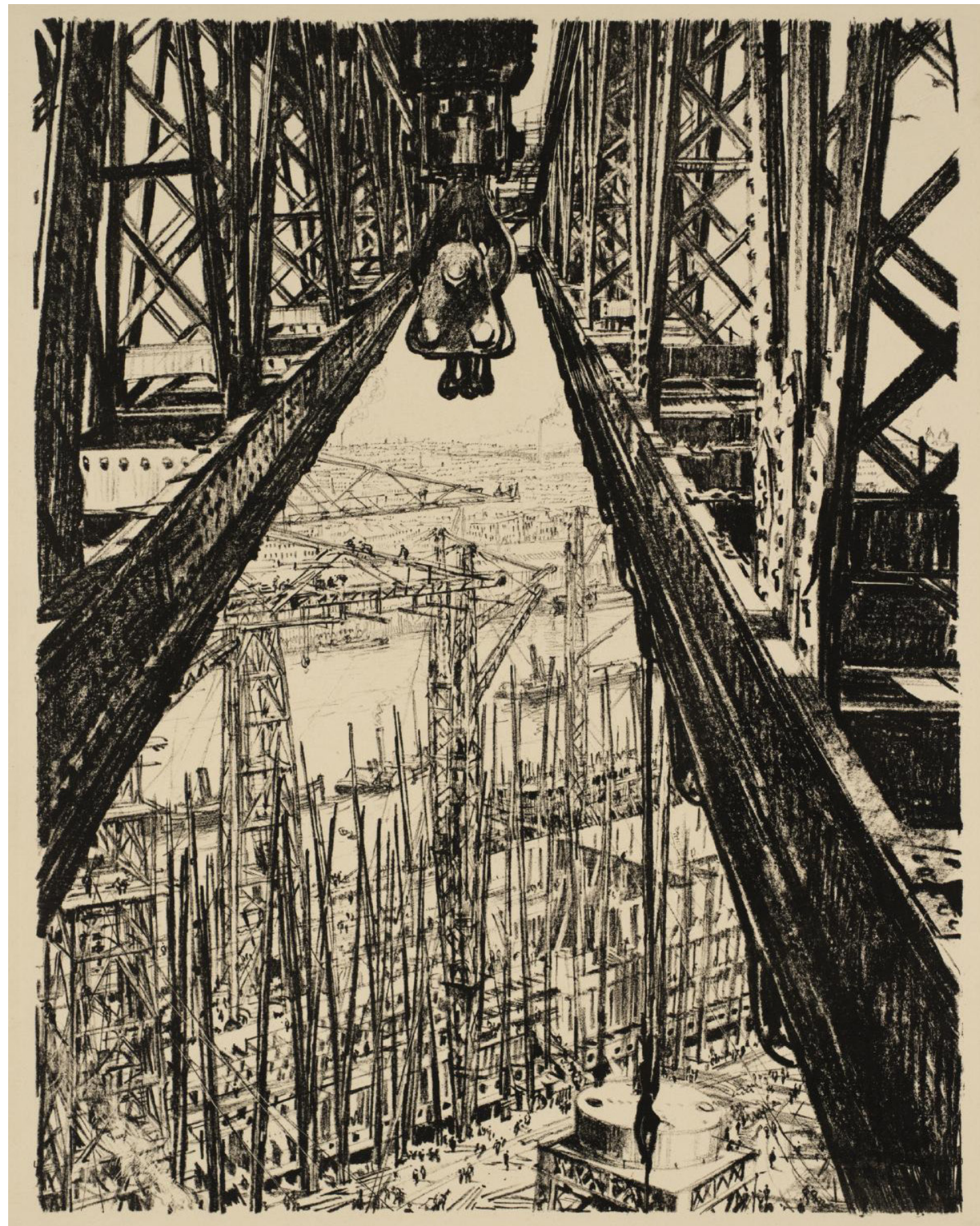

Figure 4: Muirhead Bone, A Shipyard seen from a Big Crane, c. 1917.

From The Great War: Britain's Efforts and Ideals, London, Ministry of Information, 1917. 


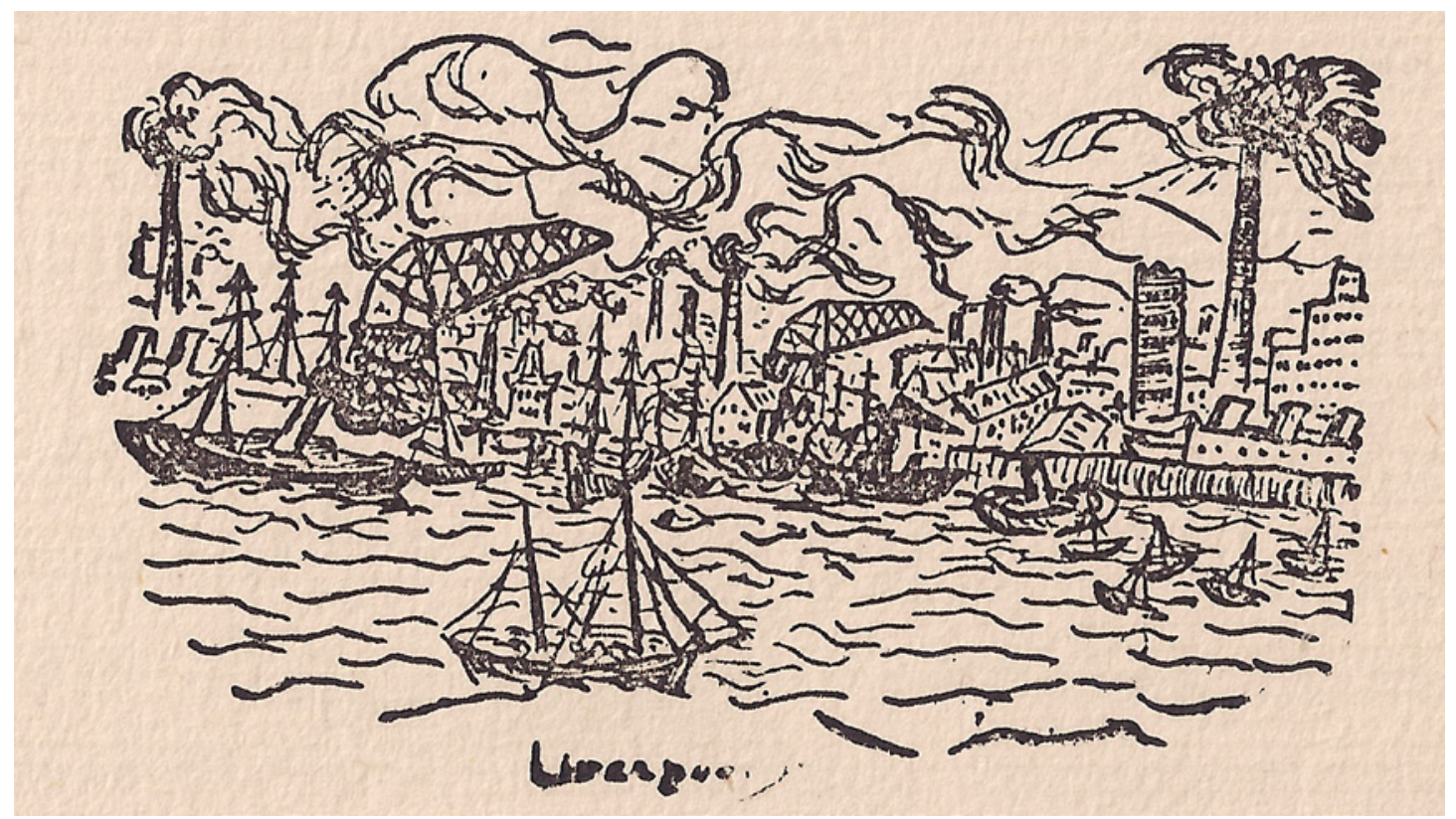

Figure 5: Karel Čapek, Liverpool.

From Letters from England, London: Geoffrey Bles, 1925, 162.

History Museum (43 /47) (Figure 6). For all the move towards abstraction this includes, it also now contains one human figure. In some respects, it is a composite equivalent of the Liverpudlian, Glaswegian and London images. Hence, he gives us another distant view of a built environment, this time surmounted by an out-of-proportion array of crystalline forms and seen past a kneeling, beseeching human figure. The diagonals of the crystals jut forward, up and out assertively and randomly. Projecting into and filling the space above the horizon they dominate that line's row of diminutive buildings. Now, rather than the viewer-threatening horrors of serried, shrieking signboards, Čapek presents us with an orderly arrangement of architectural types, the roofs, spires and towers of which point harmoniously towards the heavens. Reading from left to right, the selection of religious and civic buildings moves from a Gothic church to a minaret. The journey takes us past: a pyramid; terrace of three townhouses with pitched roofs; church with twin towers surmounted by cross-bearing cupolas; a low, vernacular- or austere neo-classical- type house with a single central chimney; a building with quadrangular tower and flat roof that may be a modernist church, town hall or factory; and an open structure reminiscent of a large gate with canopy.

This trans-cultural street from which the giant crystals erupt makes manifest Čapek's theory of crystalline structure as a fount for the forces of nature, and, with that, art. In visualising it he accords with the new wave of 'crystal modernism' that derived from Symbolism and Cubism, and which was to be particularly strongly expressed by Czech artists, designers and architects from Kupka, Zrzavý and Foltýn to Chochol, Gočar, Janák and others. He expressed his crystalline theory, and with it an explanation of his image, in the surrounding pages of the book: 


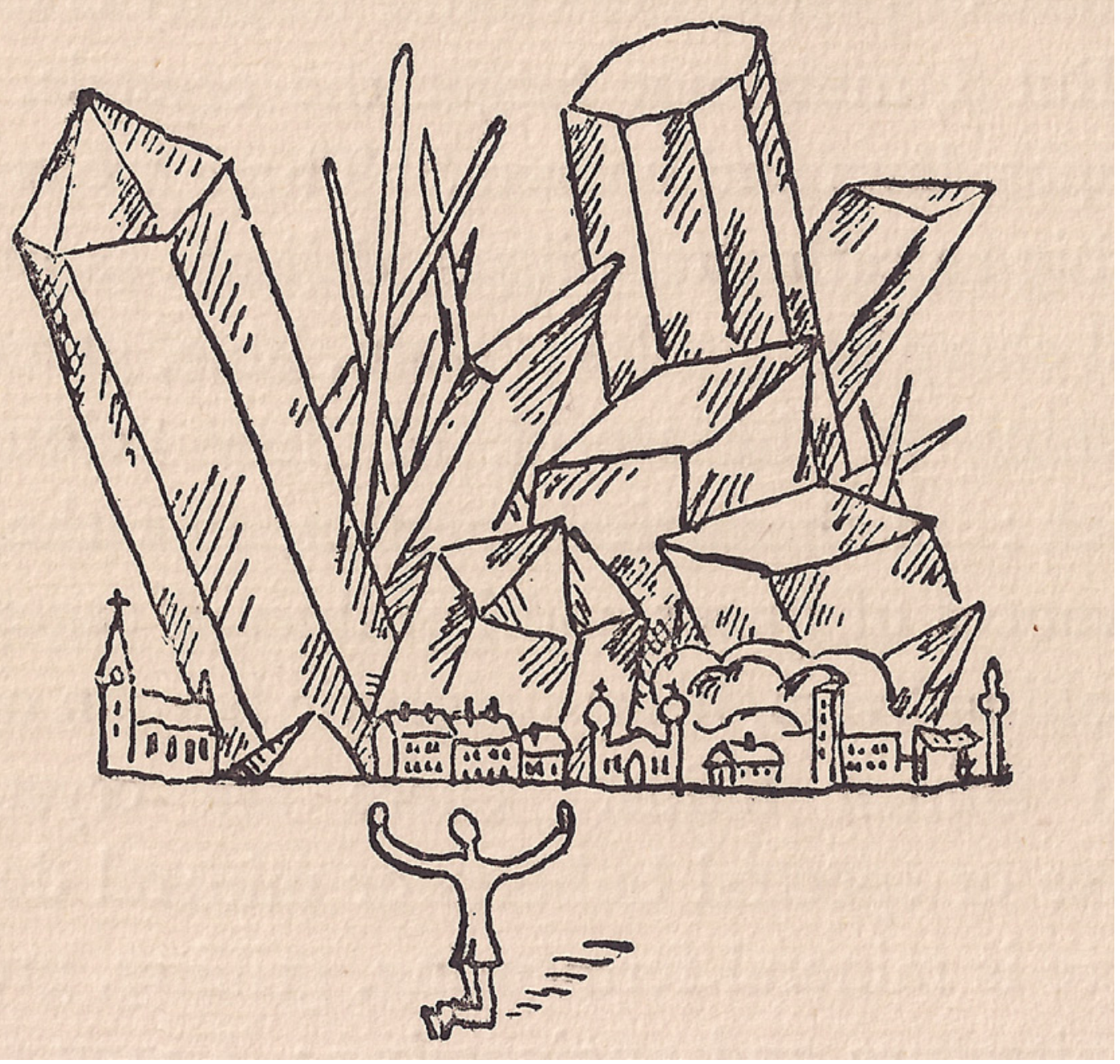

Figure 6: Karel Čapek, Crystal Life.

From Letters from England, London: Geoffrey Bles, 1925, 43.

Yes, nature is strange and mighty: and I, an unwearied pilgrim to pictures and statues, must confess that I derived the greatest delight from the conches and crystals in the Natural History Museum... I must not forget the crystals, their shapes, laws and colours. There are crystals as big as cathedral pillars, delicate as mildew and sharp as needles... there is mineral fermenting, melting, growth, architecture and engineering. I vow that a Gothic church is not the most complicated of crystals. Even within us there persists a crystalline power. Egypt crystallised in pyramids and obelisks. Greece in columns. The Gothic in pinnacles and London in cubes of black mud. Countless laws of construction and composition run through matter like secret mathematical lightning flashes. We must be exact, mathematical and geometrical, in order to be equal to nature. Number and fantasy, law and abundance are the feverish forces of nature. Becoming a part of nature does not mean sitting beneath a green tree. No, it means creating crystals and ideas. This means creating laws and forms: penetrating matter with incandescent lightning flashes of divine calculation (41-45/45-48). 
This crystalline theory of creativity articulated an aesthetic that is familiar not only from the work of artistic contemporaries such as Feininger, mentioned earlier, but was more generally a topos in Central Europe, as in, for example, Kálman Harsányi’s novel The Crystal Viewers (A Kristálynézők) of 1914, whose cover and frontspiece were designed by the Gödöllő artist Sándor Nagy (Figure 7). Furthermore, both theory and image accord with those of Čapek's fellow Bohemian Wenzel Hablik, evident in his cosmic crystal etchings, such as Creative Forces (1909) and paintings such as Crystal Castle in the Sea (1914) and The Path of Genius (1918) (Figure 8). ${ }^{17}$

\section{Town, country and human lines}

The spread, growth and ordered variety of Čapek's crystal townscape, with its squarish format, provides relief from the compressing, stagnating vertical elongation and one-point perspective of his London street scene. Comparison of the two, with Glasgow and Liverpool in between, suggests a range to his intermodernist worldview that is all the better comprehended by examination of other graphic representations of the built environments and architectural spaces he encounters on his travels around Britain. His treatment of these is encumbered with his ideas concerning the possibility of a positive, peaceful and fair community (and concomitant anxieties about systems of egregious, discriminatory, exploitation). Those images, which employ centralised elevated viewpoints, single-point perspective, symmetry and, often, elongated verticality, might emphasise artificiality and the hierarchical thinking of their buildings' creators, but their formal traits can also show subtle varieties thereby enhancing what Čapek perceived to be their preservation of a humane connection between the traditional and the modern, the rural and the urban. Hence, for example, his 'elevated viewpoint' may well be more appropriately termed 'bird's eye.' That said, the image that most closely follows his aerial view of London Traffic is one summarising his appreciation of the stock of London's museums (particularly, no doubt, the British and Victoria and Albert Museums) (47/50) (Figure 9). Now, however, it is the accumulated collections that are ranked along the blind diagonals leading to the vanishing point. Facing one another. the tall, flat, homogenised displays (in which nothing can be seen) squeeze between themselves an endless path. This is populated only by: occasional 'attendants,' hunched over as if sleeping in their upright chairs, their backs turned to the collections; a scampering spaghetti figure (Čapek's caricatural self-portrait); three tiny, still, ant-like figures, isolated in the midst of their giant surrounds. In this case the image is a pointed, reductive, graphic counterpart to a variety of thoughts that are worth citing at length for their biting, witty criticism of systemic British negligence with regard to peoples' art:

... none too creative herself... [w]ealthy England has amassed the treasures of the world in her collections... I now should assuredly be very learned about various styles and cultures... the development of art... instead... I have rent my garment and... do not know which is more perfect: to be a cave-man or a Briton in the West End... nowhere behind or before us is there a point of rest, of

17) Hablik was a participant in Bruno Taut's Crystal Chain chain letter which advocated a form of utopianist, Expressionist architecture (1919-20). 


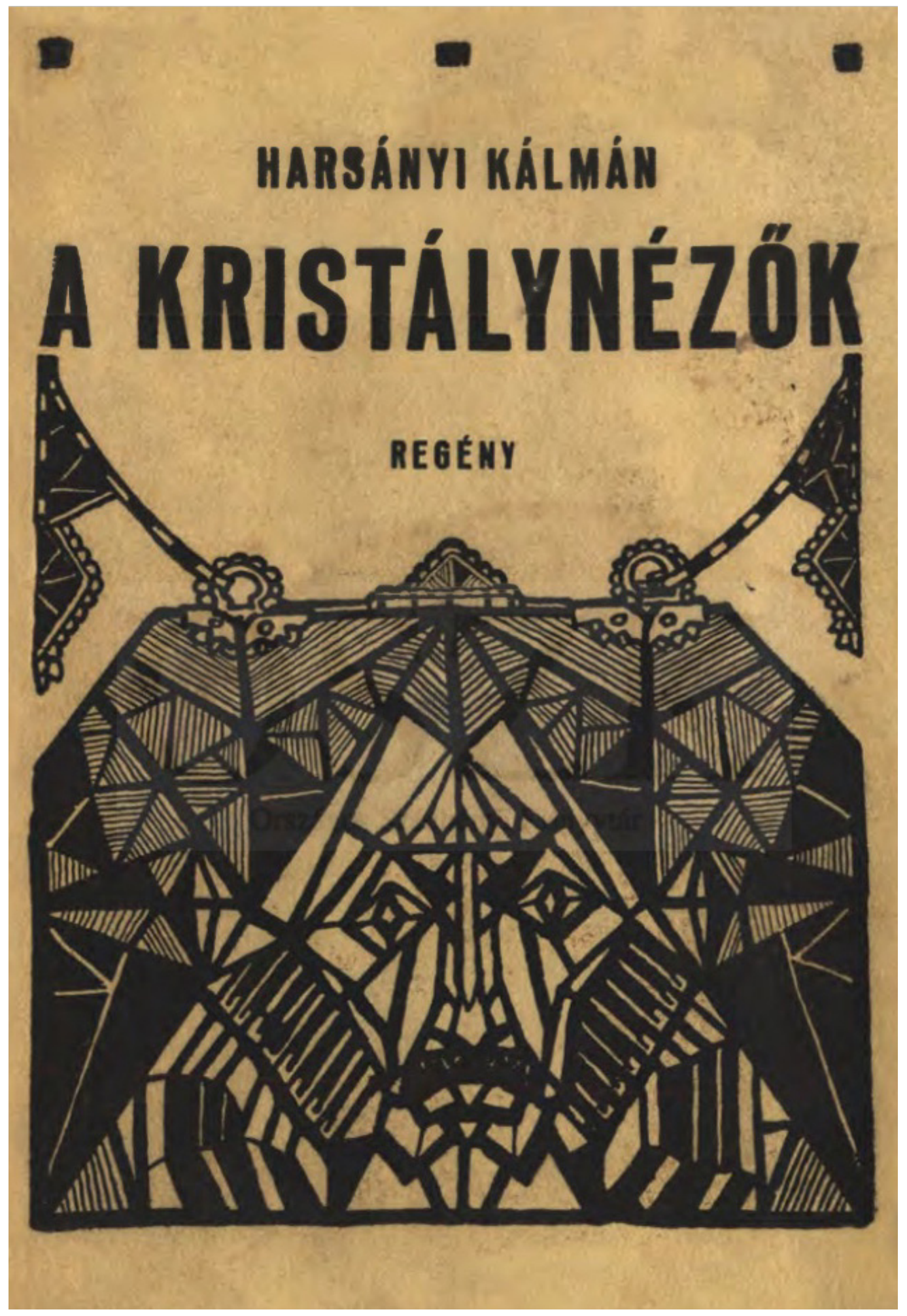

Figure 7: Sándor Nagy, Front cover of Kálman Harsányi, A Kristálynézök (Crystal Viewers), Budapest: Toldi Lajos, 1914. 


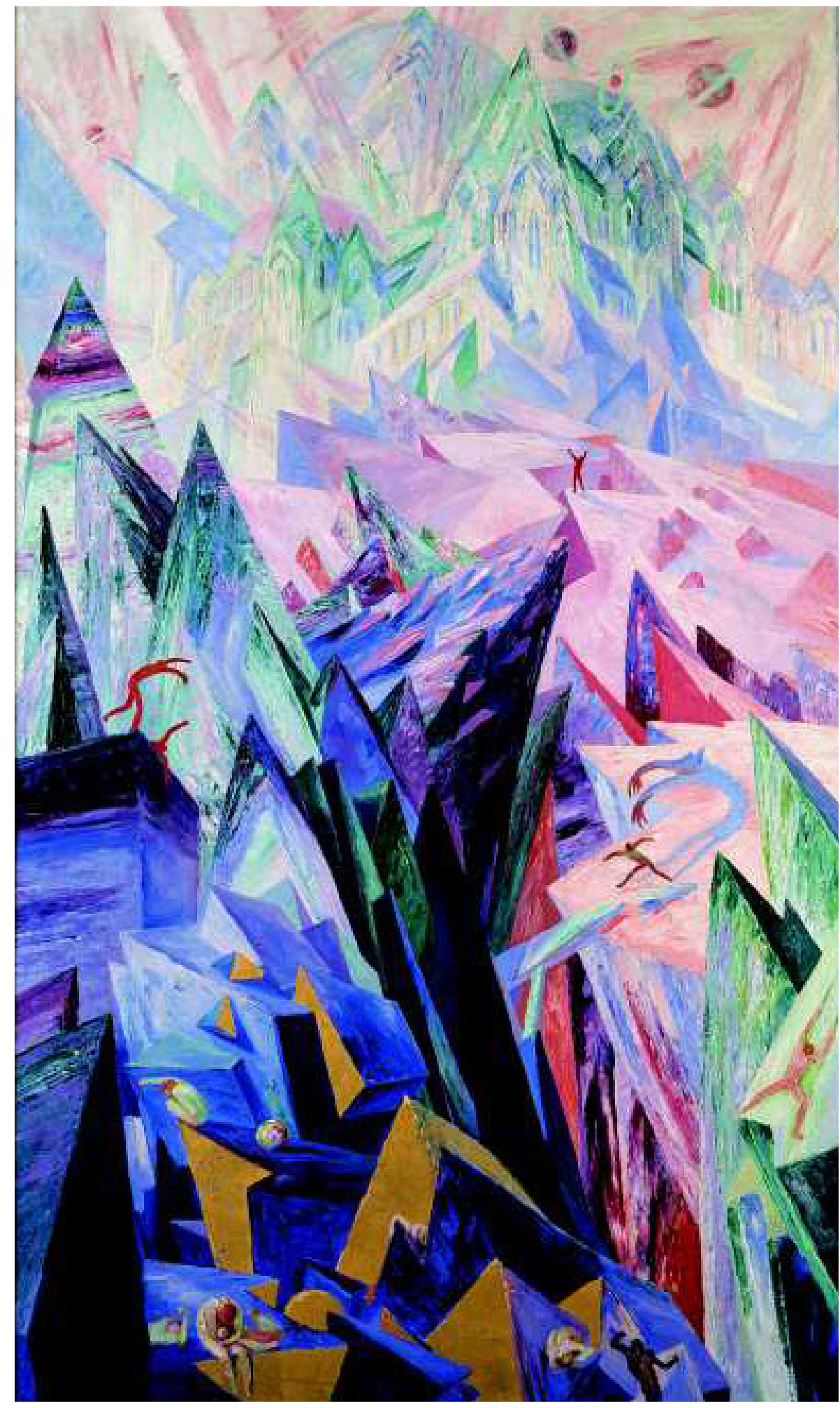

Figure 8: Wenzel Hablik, The Path of Genius (1918). 
an ideal, of the completion and perfection of man... it is everywhere and nowhere... there is no 'up' or 'down'... only an unendingly new creativity... the only lesson to be learnt... [is] create like madmen, create unceasingly... leave this accumulation of all the world's treasures and ride for hours and miles on top of a bus from Ealing to East Ham, and Clapham to Bethnal Green... and you will scarcely find any human achievement that will please you with its beauty and luxuriance... Art is what is deposited behind glass in galleries, museums and the rooms of rich people... it does not move about here in the streets... perhaps after all it is simply Protestantism which has drained this country dry artistically (46-50/49-52).

One other image serves to demonstrate the alienation Čapek experienced in establishment Protestant England. This is a view that summarises his experience of the 'English cathedral' (92/84), extrapolated as it is from visits to Ely, Lincoln and York (Figure 10). Here again he adopted the vertical, compressed format we see in Museum and Traffic. Now, however, the stripping of human and creative spirit is emphasised by the fact that the nave and choir are empty of worshippers and art, their boundaries marked in the foreground by camp 'sacristans' keeping the people out and, in the distance, by an organ. The adjectives he uses to describe this perceived profanation of beautiful, religious space, include: dour, bare, strange, spoilt, absurd (90-91/83-84).

In order to complete our grasp of Čapek's intermodernist perception of British identity, and, indeed, his cry for simple, boundary-crossing, human relations, we should first turn to the 'Reminiscences' that conclude his Pictures from Home. Writing in 1938, just before his death and as Czechoslovakia was to become a fulcrum for Fascist-led apocalypse, he summed up his appeal for mutual understanding based on everyday social interaction rather than 'the custom of somehow identifying a country and nation with its politics, regime, government, public opinion or whatever that is called.'18 For Čapek, 'imagination,' 'memory,' 'something quite casual and mundane,' based on individual direct experience and observation, was primary. ${ }^{19}$ Hence he cites chance quotidian encounters and exchanges between travellers and locals as a way of advancing peace and civilised respect. He envisages himself as the archetypal gregarious humanist finding a common language with others through polite, momentary, personal intercourse. In railing against the tide of segregating political forces that are leaving both nations and individuals at odds, and 'all the more and more alone', he recalls, with warmth, a scene of an old gardener and girl cyclist he noticed by an 'ordinary house in Kent,' which he now misses, and which sums up 'all of England.'20

The editor of Pictures of Home decided to illustrate Čapek's reminiscences with his picture of a house and garden from Letters from England (169 /133) (Figure 11). This had first appeared in The Manchester Guardian, where, unlike the book editions, it accompanied his eulogy to Oxbridge life... just before his condemnation of the spirit of English cathedrals. Now the high viewpoint and illusory depth lead the eye past a garden replete with indistinct interacting figures, box forms and bushes to a large cottage whose multiple irregular windows and chimneys argue for picturesque craft and community. He commented: 'I drew, without claim

18) Čapek, Obrázky z domova, op. cit., 121. Translation by the author.

19) Ibid.

20) Ibid., 121-122. 


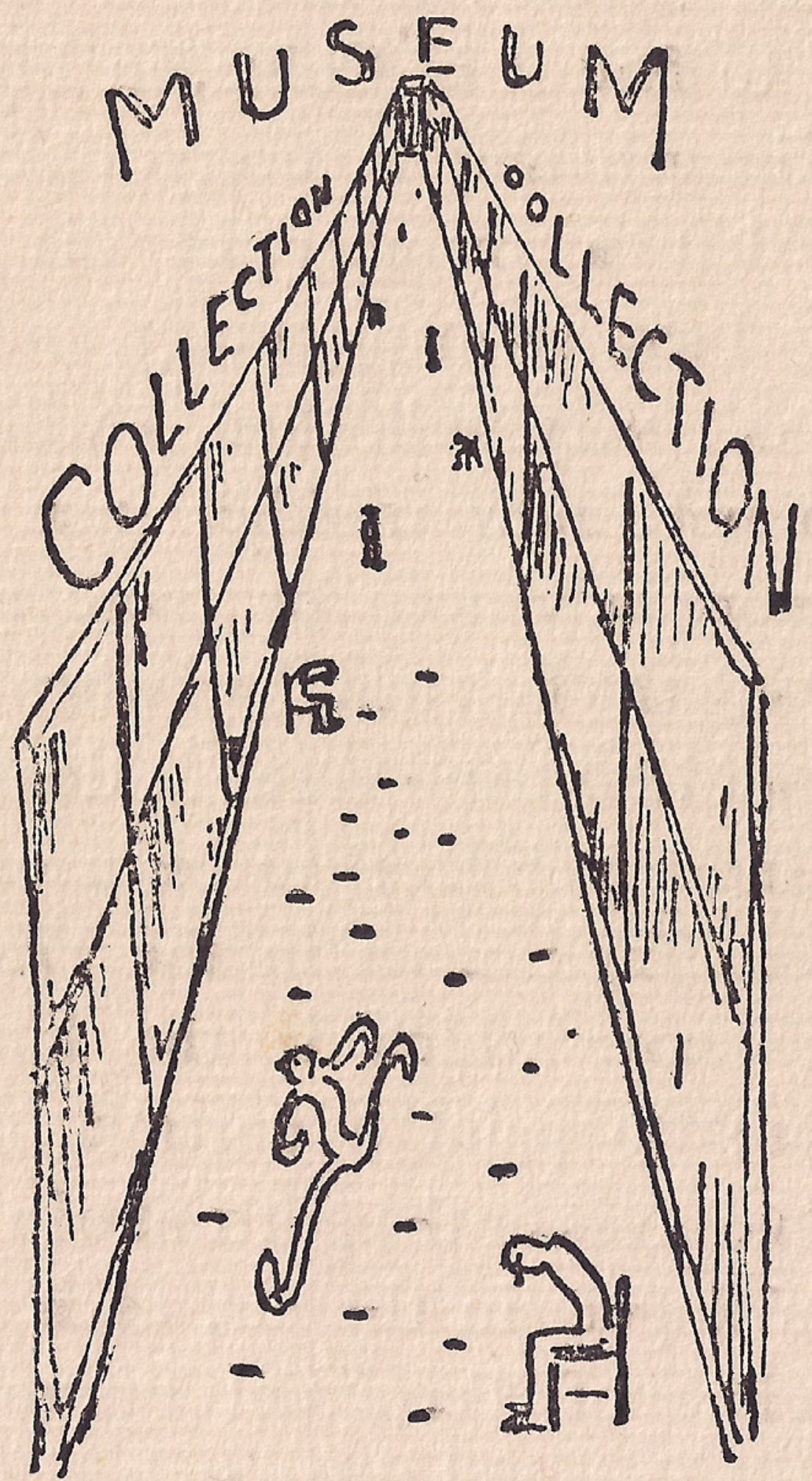

Figure 9: Karel Čapek, Museum.

From Letters from England, London: Geoffrey Bles, 1925, 47. 


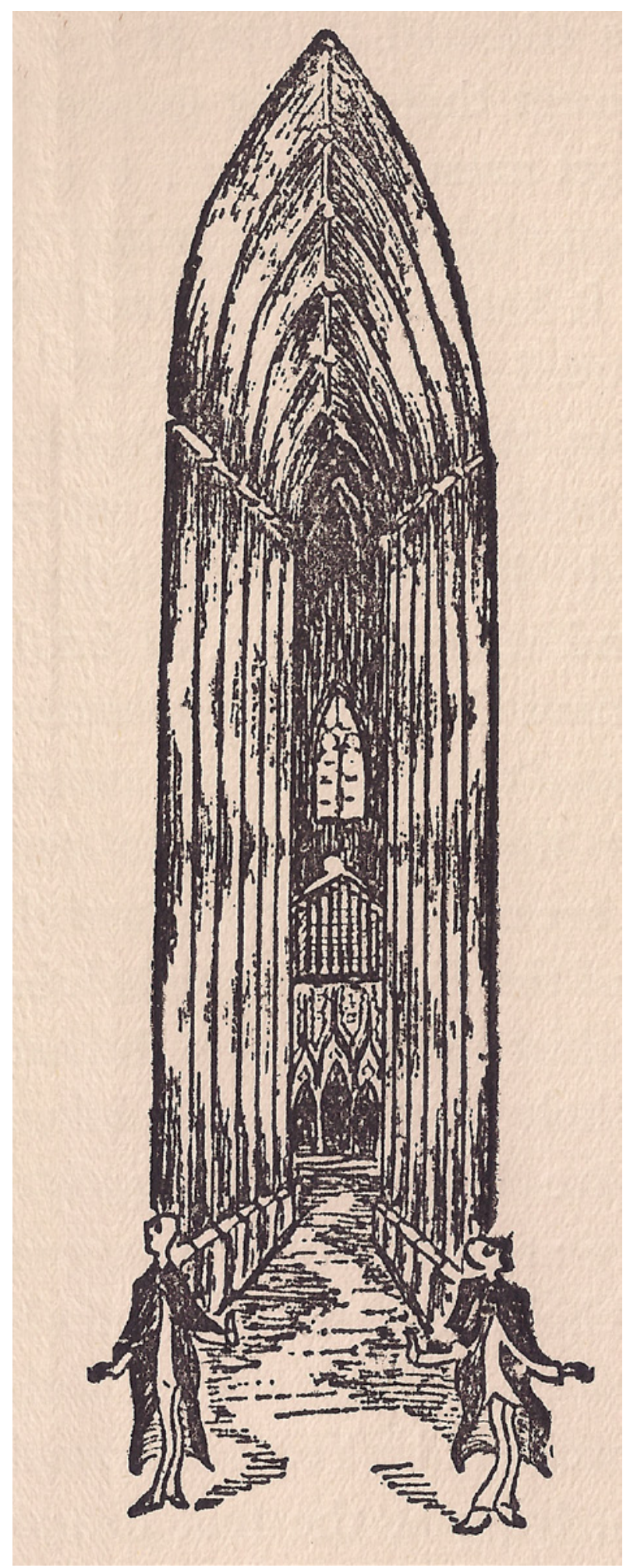

Figure 10: Karel Čapek, Cathedral.

From Letters from England, London: Geoffrey Bles, 1925, 92. 


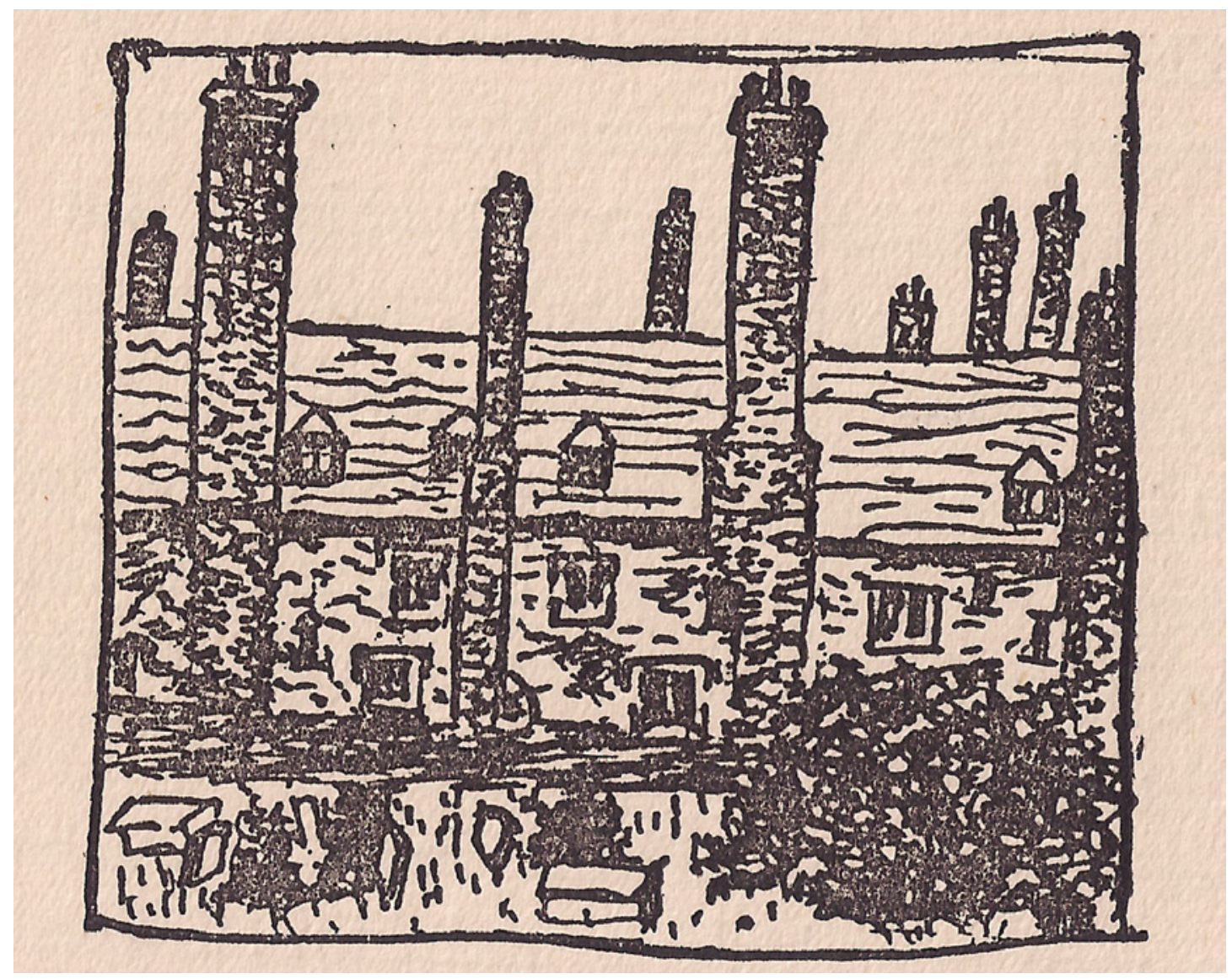

Figure 11: Karel Čapek, Symphony of Chimneys.

From Letters from England, London: Geoffrey Bles, 1925, 169.

to recognition, from a window a sort of symphony of chimneys, but that need not have been done in Cambridge; all old English towns possess the same type of chimney.21

Čapek conveyed an abiding empathy for the pastoral in Letters from England. And despite the title of his book this is nowhere more apparent than in his images and writing of Scotland. With these he extolled ideas of modern life based on ancient convention and forged over centuries by a combination of migrating and settled folk working with local materials and nature. Suddenly he uses 'beauty,' 'beautiful' and 'sublime' to describe scenes and life that he also sees as 'poverty-stricken,' 'native,' 'terrible and lovely', but possessing attractive 'strangeness' and, thereby, arousing 'unknown and divine virtues' (119-120/102-104). He sums this up with his image of turf-roofed and ruined cottages set against a backdrop of the Cuillin mountains on the Isle of Skye (Figure 12). Now his high viewpoint and combination of straight and curved lines open up space, giving a sense of organic depth and spread within and across the horizontal composition. The effect is one of harmonic communion of vernacular culture with the landscape. He whimsically locates these alongside, for example, a typecasting of Scots, who, being 'sturdy, with florid faces and powerful necks,' are treated to a caricature of a stolid-headed, 'characteristic' Scottish couple (109/95) (Figure 13).

21) Karel Capek, 'How it feels to be in England,' The Manchester Guardian, 27 September 1924, 11. 


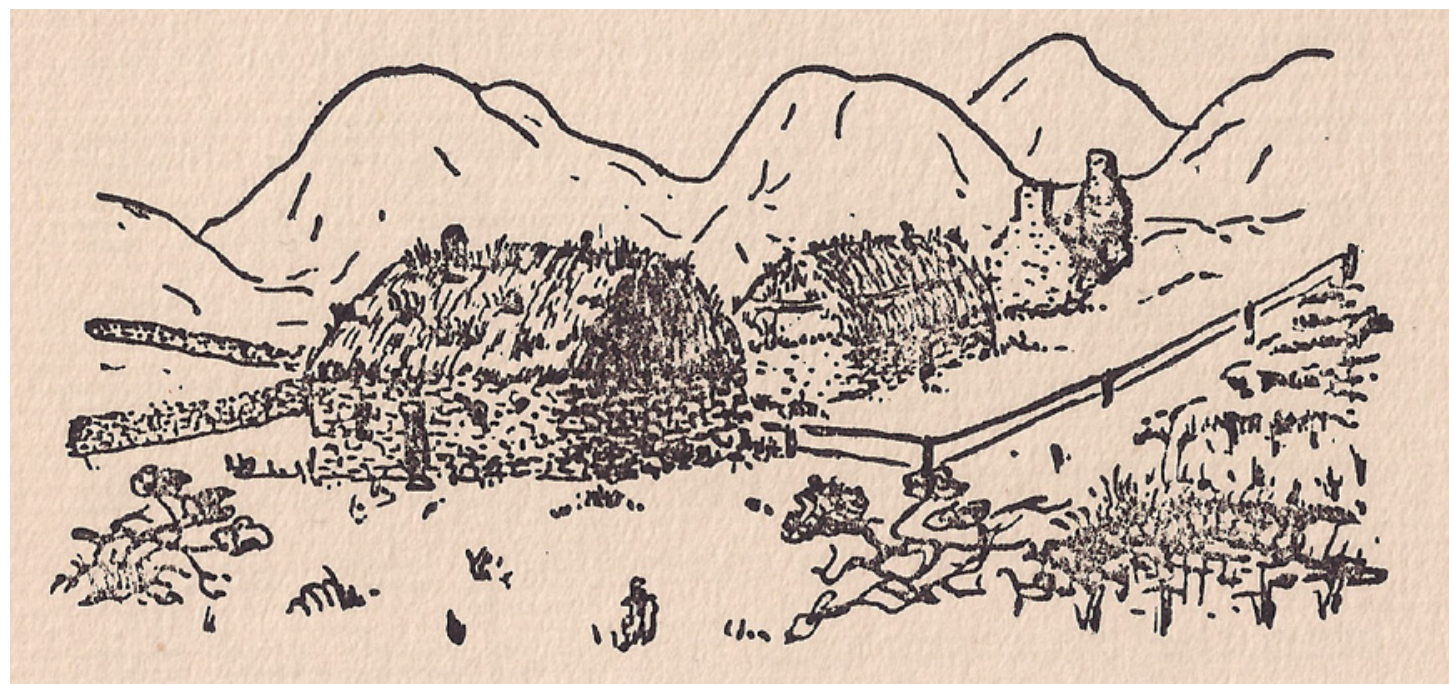

Figure 12: Karel Čapek, Skye or Terra Hyperborea.

From Letters from England, London: Geoffrey Bles, 1925, 119.

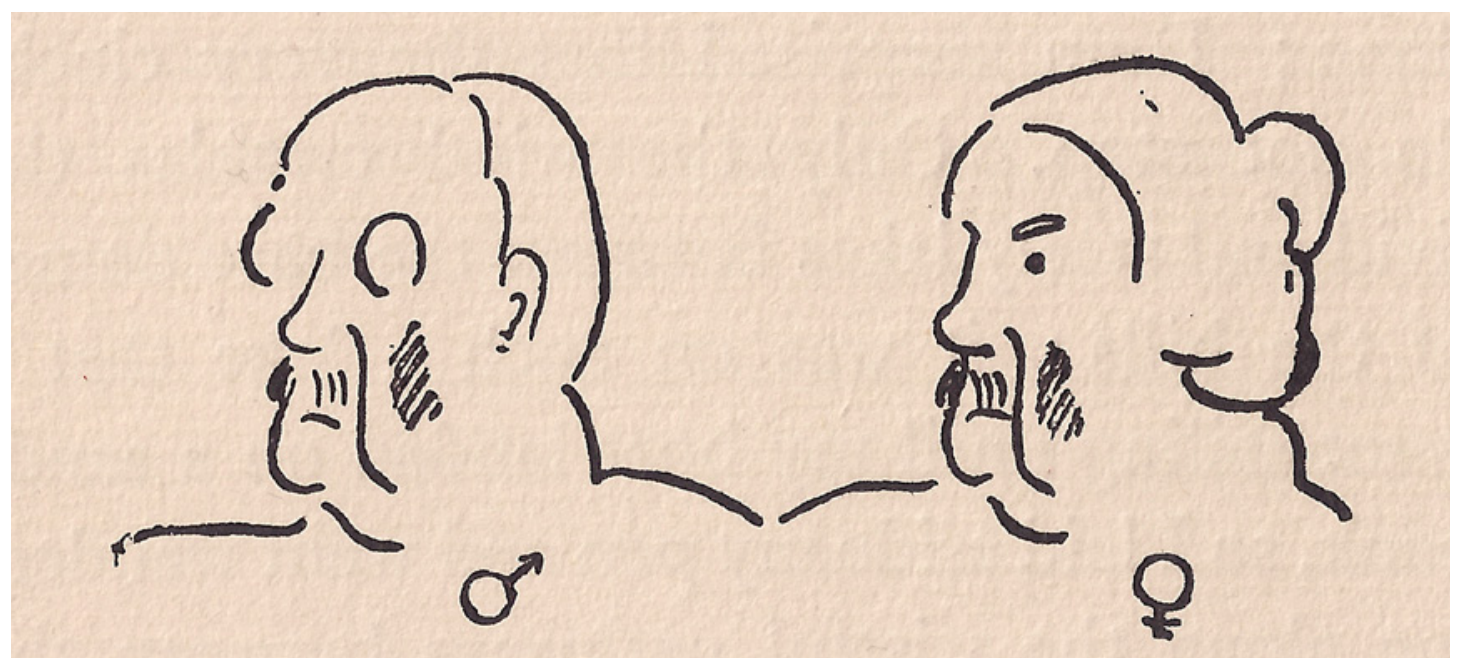

Figure 13: Karel Čapek, A Scots Couple.

From Letters from England, London: Geoffrey Bles, 1925, 109.

Čapek's reading of Scottishness through the places and types of his drawings, does have a second English counterpart, this also being the work with which we may complete our enquiry, bringing us full circle back to southeast England. On page 82 / 76 of Letters from England he includes a sketch of a large house surrounded by tall trees and a meadow or lawn. He adds the words 'Easton Glebe,' 'Cuckoo' and 'Rabbit,' the latter two with arrows pointing towards them (the cuckoo being invisible in a tree) (Figure 14). Easton Glebe is actually a mideighteenth century red-brick house with a pedimented entrance and early-twentieth century semi-circular eastern extension, both of which are visible in Čapek's drawing. It is located 


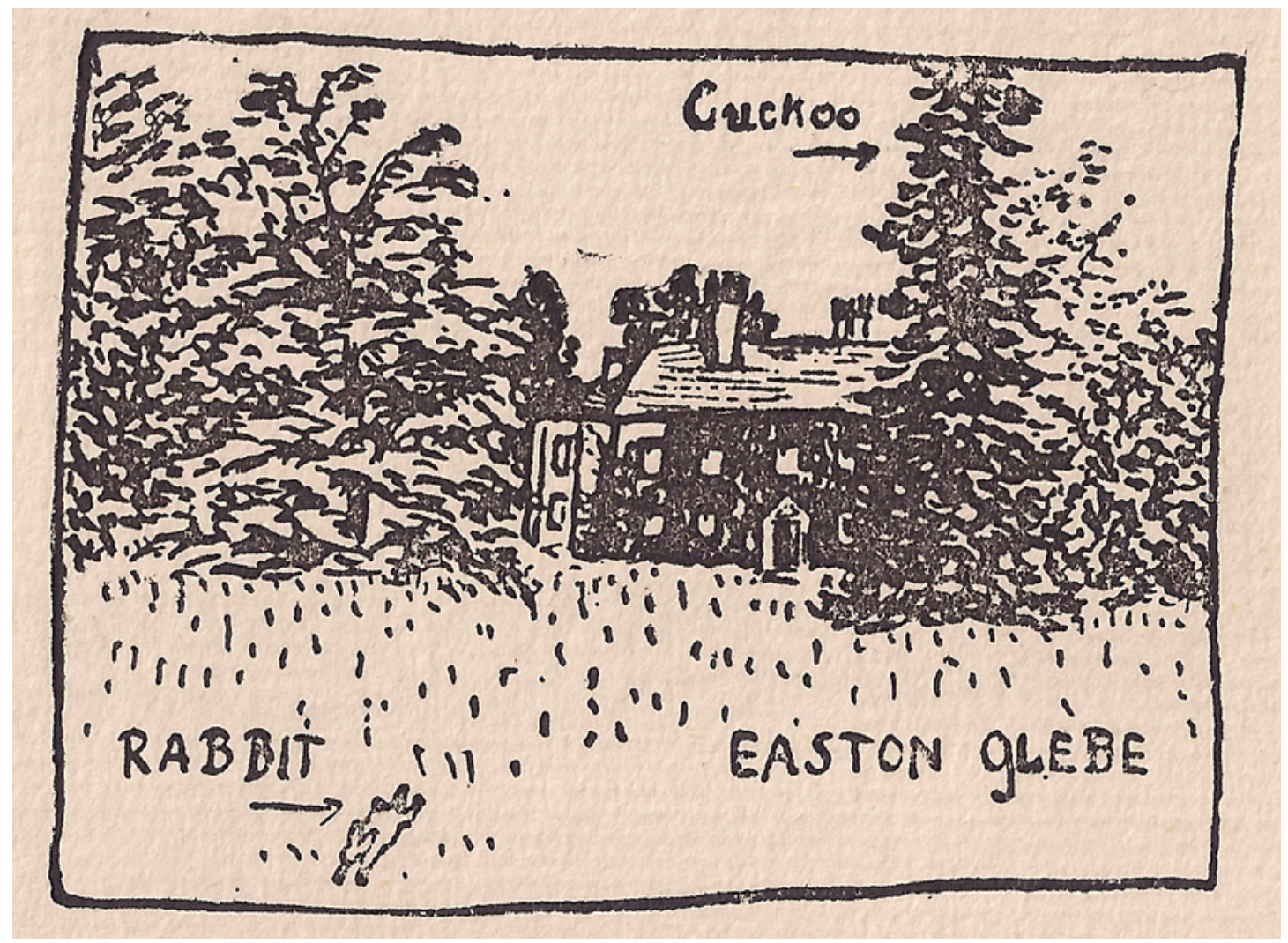

Figure 14: Karel Čapek, Easton Glebe.

From Letters from England, London: Geoffrey Bles, 1925, 82.

in rural Essex, five kilometres northwest of the market town Great Dunmow. The pastoral serenity of the scene is enhanced by his low viewpoint, the landscape format and avoidance of vanishing point. His written text is devoid of the jaundiced language found elsewhere, instead according with the lyricism of his view:

I roamed like a fairy... marvelled at the harmony and perfection of the life with which the Englishman surrounds himself in his home... inside there lives and writes one of the most reasonable men in this world, and outside the cuckoo cuckoos as much as thirty times in succession. Thus, I conclude my tale of the best things in England (83/76-77).

He does not disclose in writing that this 'most reasonable' of men and 'best thing' was H. G. Wells and that it was his country home in Essex, even though the 'Easton Glebe' in the image gives them away. Furthermore, this encounter with the (science fiction) author and man who Čapek regarded as inspirational, is subject to two caricature portraits (public and private faces) much later in the book (180/141) (Figure 15), the appearance of which confirms the familiar terms between the two writers as a result of Čapek's stay there. He sums up Wells's appearance in a way that encapsulates the quest for a balance of integrated tradition, nature and individual creativity that informs his imaginative study of cultural process: 'a massive head, strong, 


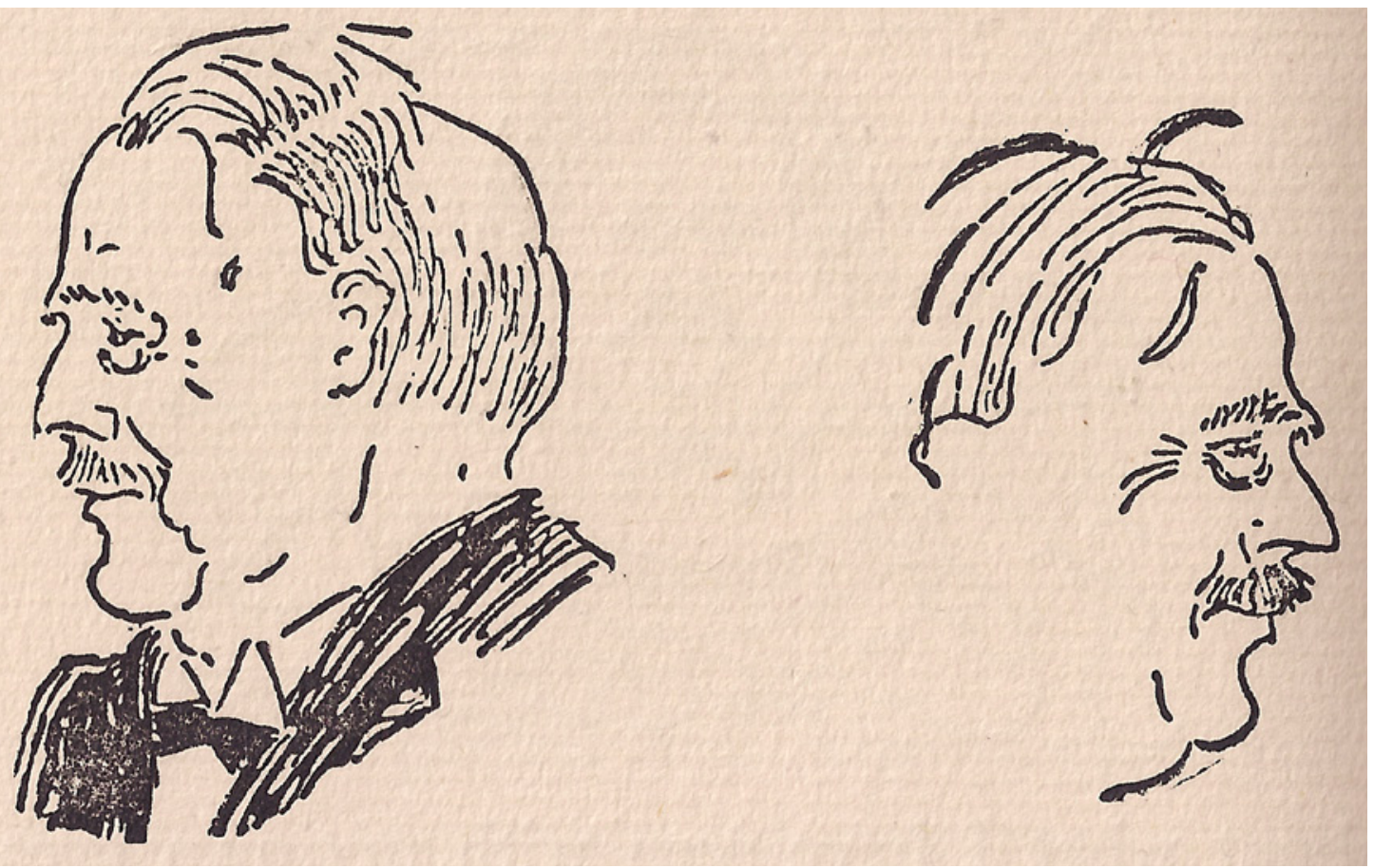

Figure 15: Karel Čapek, H.G. Wells.

From Letters from England. London: Geoffrey Bles, 1925, 180.

ample shoulders, strong and warm hands; he resembles a farmer, a worker, a father and everything in the world' (180/141). One wonders what he would make of Wells's rustic idyll had he lived into the late twentieth and early twenty-first centuries, since it is now directly under the flight path of its neighbour, Stansted Airport. In any case, with 'Easton Glebe' and Wells, Čapek's variegated visual study of the dynamics of social interaction he encounters and perceives with regard Britain can be considered complete.

\section{Concluding remarks}

The social and intellectual sustenance that Čapek found at Easton Glebe is visually articulated through sketches that are reproduced in such a way that they cover barely one-third of a page. This contrasts with Traffic which is the only drawing in Letters from England afforded a full page (29). ${ }^{22}$ While the reasons for such disparity may lie in unknowable editorial decisions, the fact that the image of London is given such prominence belies the overriding anxieties about English modernity that pervade Čapek's book. In any case, what we can glean from the scale, place and slant of his picture lines is that he is articulating what we consider an act of visual intermodernism. This is new for our understanding of Čapek and his oeuvre. While Bleumel's concept of intermodernism is a literary category coined in relation to the mid-twentieth century,

22) The poor reproduction of Traffic (p. 38) in the later Newsome edition, as noted above, is accompanied by a line of text. 


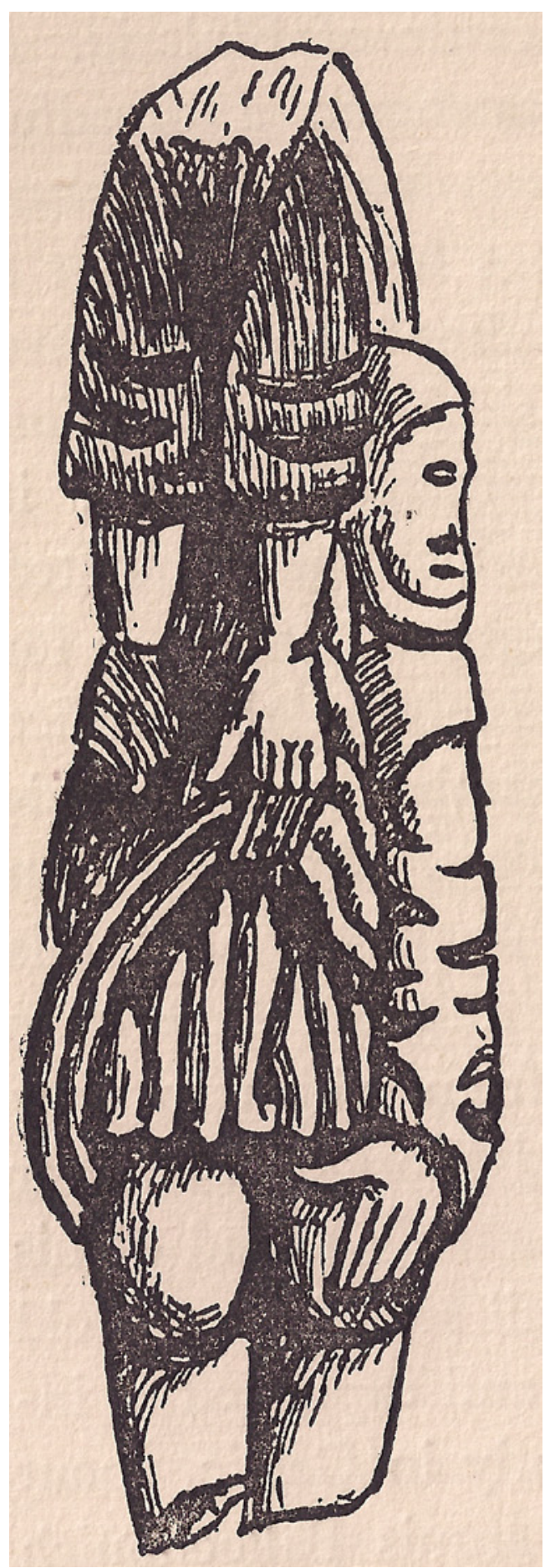

Figure 16: Karel Čapek, Castle Finlarig Sculpture.

From Letters from England, London: Geoffrey Bles, 1925, 108. 
her challenge to monolithic concepts of modernism, particularly that of 'high' modernism as a form of experimental self-reflexivity and urban-technological progressivism, is applicable to Čapek. For his travelogue artwork, as reproduced first in Letters from England, contains features that accord with Bleumal's notion of the intermodern. His is an eccentric pen-and-ink integrationist perception. And it is one where the slants of his lines are as metaphorical as they are visual. For his is an art that utilises the superficial to probe depth, the momentary to convey the universal. Thus, he derives and conveys truths through skew, in both image and word. This is Čapek's point. These are Čapek's vanishing points.

\section{Epilogue}

Concerning a sculpture at Castle Finlarig, Loch Tay, Scotland (Letters from England, p. 107-8 / 93-94) (Fig. 16):

the castle at Finlarig... there is a chamber with statues there; .... There is a ... statue which is very peculiar, and concerning it the old custodian, evidently following the ancient ballads, stated that it represents a sharp-tongued woman; and because she was beyond endurance, the sheriff decided that all those afflicted should publicly slap her backside, which the statue in question apparently depicts. I differ from the opinion of the local authority, in that this statue seems far older than sheriff, mouthy woman or Castle Finlarig; I think it represents something very ancient, perhaps the suffering of the damned in hell. Anyhow, I made a very careful drawing of it. ${ }^{23}$

23) Newsome (ibid., 175) claims 'there are no statues at Finlarig Castle, the tale of the sharp-tongued woman is not known there'. 